\title{
GertJan B. van Ommen 28 September 1947-7 November 2020
}

\author{
Mary Rice ${ }^{1}$
}

Published online: 16 December 2020

(c) European Society of Human Genetics 2020

"GertJan was the heart of the EJHG. We will remember his enthusiasm, his argumentation, and all he did for the Society in general. We thank him." said ESHG President Alexandre Reymond, opening the Board meeting that took place on Friday 13 November.

This sentiment will be echoed by all who knew and worked with GertJan, who was editor in chief of the European Journal of Human Genetics for the last 25 years, as well as being president of the ESHG in 2002-2003, and the ESHG Award Laureate in 2011. In the interview he gave for the latter, he summed up his approach to science-and to life. "I like to do repairs; to look at things, find out what's broken, and then do something about it."

GertJan undertook his studies in Amsterdam, where he lived until his death. He was head of the Human Genetics department at Leiden University Medical Centre from 1992 to 2012. His main scientific interest was in neurodegenerative and neuromuscular disorders such as Huntington's disease and Duchenne muscular dystrophy. He made major contributions to the treatment of both, for example discovering a therapy that induced exon skipping in DMD. He was one of the first to see this potential use of exon skipping: "We can use it for interfering in biological processes like moving proteins around and blocking signals. The interesting thing about antisense RNA relative to RNAi is that you can tweak its activity more precisely, rather than just destroying it, and thereby regulate many different processes."

He will be remembered for his scientific prowess, but it is perhaps his humanity and wit that will linger longest in the hearts of those who knew him. He was an inspiring mentor to many young scientists and enjoyed setting up collaborations. "So many people have complementary skills, but sometimes in national science policy they are too busy making people compete and forget how much more you can achieve jointly with a large group of people, especially in the science of today. I enjoy trying to get these groups of people to work together."

He admitted that he only half-seriously suggested that he might become editor of the EJHG following Giovanni Romeo ("I had been a pop music critic and then editor of a computer journal"), and said that he was honoured, but also scared, when offered the job. And what a job he made of it! The EJHG went from a bimonthly journal of a few hundred pages to a monthly with nearly 2000, and the impact factor rose steadily.

GertJan was tireless in the pursuit of excellence in every area of his life; a wonderful colleague and collaborator who will be missed by so many people. ESHG sends our deepest condolences to his family, of whom he spoke with so much affection.
Mary Rice

office@eshg.org

1 European Journal of Human Genetics https://www.nature.com/ ejhg 